\title{
Perancangan Proteksi Petir SUTET dengan Konsep Lightning Performance dan Kinerja Arrester
}

\author{
Tri Sakti Adiwibowo'; Prayoga Akbar Pandegatama² \\ ${ }^{1}$ UPDL Semarang, PLN Pusdiklat \\ ${ }^{2}$ DTETI FT UGM Yogyakarta \\ 1't_sakti_tri@yahoo.com \\ 2prayoga42803@gmail.com
}

\begin{abstract}
Lightning surges often occur on the $500 \mathrm{kV}$ SUTET (Extra High Voltage Air Line) transmission line. Therefore a reliable protection system design is needed to minimize damage due to lightning surge disruption and to maintain continuity in power flow. The authors use the concept of lightning performance and arrester performance as parameters for its reliability design. In this research, the concepts of lightning performance and arrester performance are used as parameters for their reliability design. In this case, the high category IKL (Isokreaunic Level) is used, which is 91 strikes / km2 / year. In determining the design of substation equipment, the performance of arresters at SUTET $500 \mathrm{kV}$ is also analyzed by using the margin protection formula. Based on the arrester performance analysis and calculation of the protection margin, the protection system in GITET (Extra High Voltage Main Station) is more appropriate to use MOV EXLIM $550 \mathrm{kV}$ arresters, power transformers (BIL: $1425 \mathrm{kV}), C V T$ (BIL: $1550 \mathrm{kV}), C T$ (BIL: $1550 \mathrm{kV}), B S I(B I L: 1550 \mathrm{kV})$, and CB (BIL: $1550 \mathrm{kV}$ ) with a protection margin of more than $20 \%$.
\end{abstract}

Keywords: protection system design, lightning performance, arrester performance, protection margin

\begin{abstract}
ABSTRAK
Surja petir sering terjadi pada saluran transmisi SUTET (Saluran Udara Tegangan Ekstra Tinggi) $500 \mathrm{kV}$. Oleh karena itu dibutuhkan rancangan sistem proteksi yang andal untuk meminimalisir kerusakan akibat gangguan surja petir dan tetap menjaga kontinuitas penyaluran daya. Dalam penelitian ini digunakan konsep lightning performance dan kinerja arrester sebagai parameter untuk disain keandalannya. Pada kasus ini, digunakan IKL (Isokreaunic Level) kategori tinggi yaitu sebesar 91 sambaran/ $\mathrm{km}^{2} /$ tahun. Dalam menentukan rancangan peralatan gardu induk, kinerja arrester pada SUTET $500 \mathrm{kV}$ juga dianalisis dengan menggnakan formula margin proteksi. Berdasarkan analisis kinerja arrester dan perhitungan margin proteksi maka sistem proteksi di GITET (Gardu Induk Tegangan Ekstra Tinggi) lebih tepat menggunakan arrester MOV EXLIM 550 $k V$, power transformer (BIL: $1425 \mathrm{kV}), C V T$ (BIL: $1550 \mathrm{kV}), C T$ (BIL: $1550 \mathrm{kV}), B S I(B I L: 1550 \mathrm{kV})$, dan CB (BIL: $1550 \mathrm{kV}$ ) dengan margin proteksi lebih dari $20 \%$.
\end{abstract}

Kata kunci: perancangan sistem proteksi, lightning performance, kinerja arrester, margin proteksi

98 | Energi dan Kelistrikan: Jurnal Ilmiah 


\section{PENDAHULUAN}

Indonesia adalah salah satu negara yang letaknya di sekitar garis khatulistiwa (equatorial bolt) dengan kondisi geografis dekat laut dan hari guruh per tahun yang cukup tinggi yaitu 100 sampai 200 [1]. Dengan hari guruh yang tinggi maka sambaran petir sering menyebabkan gangguan penyaluran tenaga listrik dan kerusakan infrastruktur baik pada sistem tenaga listrik, telekomunikasi, maupun peralatan elektronik. Padahal saluran transmisi memegang peranan penting yang vital dalam penyaluran daya dari pembangkit ke pusat-pusat beban. Kerusakan infrastruktur sistem tenaga listrik disebabkan munculnya tegangan lebih petir. Sambaran petir ini berkontribusi lebih dari 50\% sebagai penyebab gangguan pada sistem tenaga listrik. SUTET (Saluran Udara Tegangan Ekstra Tinggi) 500 $\mathrm{kV}$ adalah obyek yang mudah terkena sambaran petir karena posisinya yang tinggi [2]. Dengan adanya persoalan kondisi kelistrikan Indonesia tersebut yang selalu dihujani oleh sambaran petir baik langsung maupun tidak langsung, maka pihak-pihak yang memegang peranan penting (stakeholder) harus menjaga keandalan dari gangguan petir khususnya pada saluran transmisi dengan melakukan kajian perancangan sistem proteksi petir berdasarkan lightning performance dan kinerja arrester pada saluran transmisi [3].

Dari hasil kajian ini diharapkan dapat menentukan rancangan sistem proteksi pada SUTET dengan konsep lightning performance dan kinerja arrester yang memenuhi kriteria keandalan minimum good grounding and shielding dan dalam batas aman dengan margin proteksi $\geq 20 \%$ BIL peralatan [4].

\section{METODE/PERANCANGAN PENELITIAN}

\subsection{Diagram alir peracangan}

Data-data untuk keperluan perancangan diperoleh dari observasi lapangan dan studi pustaka meliputi : datasheet peralatan gardu induk dan konstruksi menara SUTET, IKL Jawa Tengah (Isokreaunic Level) dari BMKG, kawat tanah (OHGW), isolator, data saluran, dan data peralatan gardu induk. Penelitian ini dimulai pada bulan Agustus 2018 dan selesai pada bulan Desember 2018 di GITET PLN UPT Ungaran, Jawa Tengah.

Perancangan dan penelitian ini menggunakan beberapa formula perhitungan, perangkat lunak Microsoft Excell, ATPDraw 4.2 EMTP: Electromagnetic Transient Program, AutoCAD MEP 2018, dan perangkat keras. kalkulator CASIO fx-570ES untuk melakukan perhitungan dan simulasi komponen performa petir (lightning performance) [5].

Perancangan ini dilakukan dengan tahapan : Studi literatur rancangan sistem proteksi petir berdasarkan lightning performance dan kinerja arrester, studi lapangan dan pustaka terhadap datasheet rancangan sistem proteksi SUTET yang ada di pasaran, mempersiapkan perangkat perancangan, melakukan rancangan sistem proteksi petir pada menara SUTET, melakukan analisis rancangan dengan konsep lightning performance (komponen shielding failure dan back flashover) dan evaluasinya melalui Konstenko Poloroy Rosenveld Method [6]. Bila memenuhi requirement maka lanjut ke tahap berikutnya, melakukan rancangan sistem arrester dan perhitungan margin proteksi. 


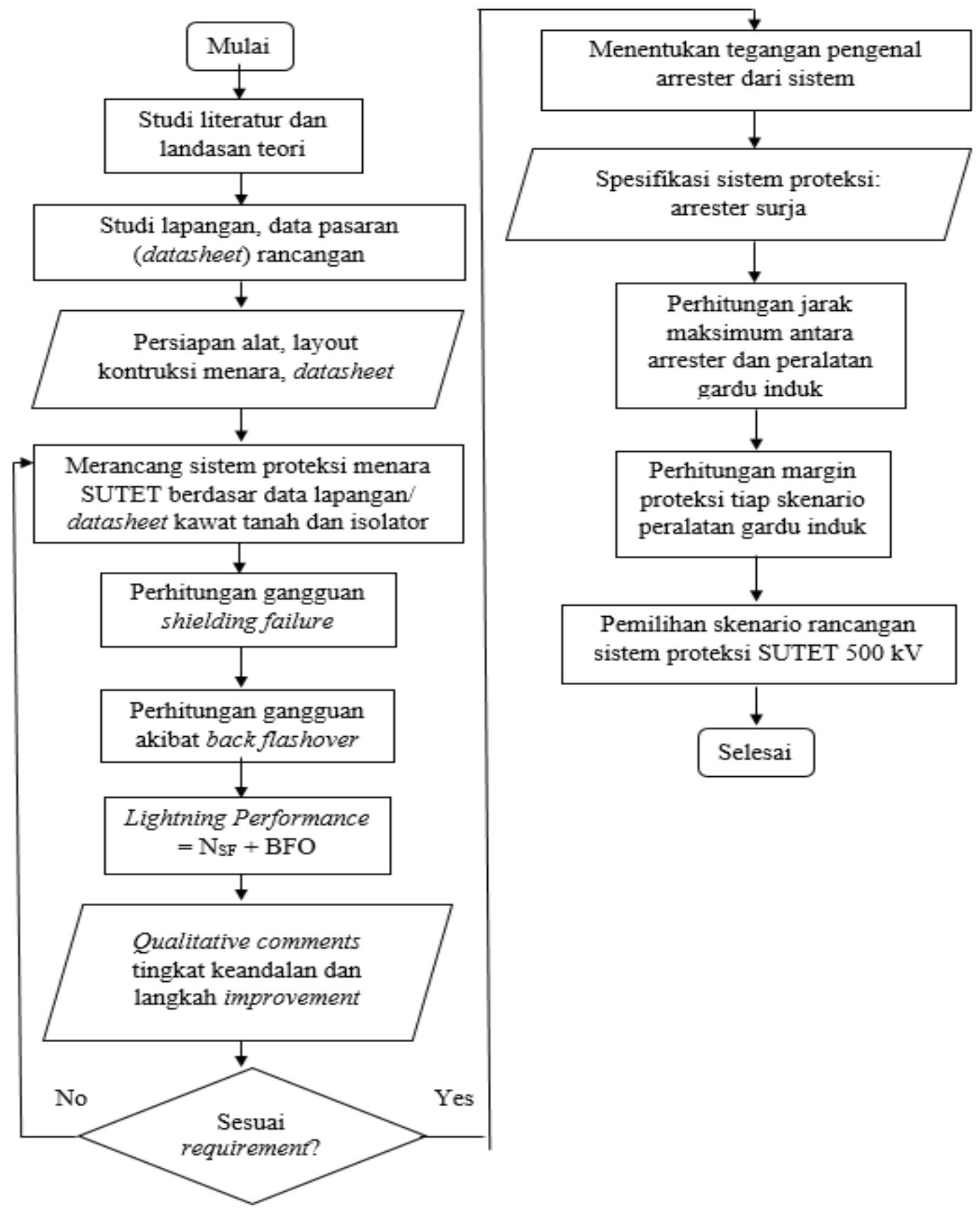

Gambar 1. Diagram Alir Langkah Perancangan Sistem Proteksi Petir SUTET 500 kV Berdasarkan Konsep

\subsection{Persamaan Matematika} LightningPerformance dan Kinerja Arrester

Radius amplop korona: $R \cdot \ln \left(\frac{2 h}{R}\right)=\frac{V_{50 \%}}{E o}$.

Radius ekivalen kawat berkas: $r_{e k i}=\sqrt[N]{r 1 . d 12 . d 13 \ldots d 1 N}$

Impedansi surja kawat masing-masing fasa: $Z_{\emptyset}=60 \sqrt{\ln \frac{2 h}{r_{e k i}} \ln \frac{2 h}{R c}}$.

Arus petir minimum yang menyambar tiap kawat fasa : $\mathrm{I} \min =\frac{2 V_{50 \%}}{Z_{\emptyset}}$.

Jarak sambaran minimum Smin $=6,7 \times \operatorname{Imin}^{0,85}$

Daerah tidak terlindungi $X s=S(\cos \theta+\sin (\alpha s-\omega)$

100 | Energi dan Kelistrikan: Jurnal Ilmiah 


\section{HASIL DAN PEMBAHASAN}

Dengan mengikuti teori dan metode penelitian yang telah dijelaskan, dilakukan perhitungan Lightning Performance (LP) yaitu jumlah gangguan akibat sambaran langsung pada model menara transmisi $500 \mathrm{kV}$ [7]. LP merupakan jumlahan dari gangguan akibat shielding failure $\left(\mathrm{N}_{\mathrm{SF}}\right)$ dan gangguan akibat back flashover (BFO) [8]. Menara transmisi yang dijadikan objek adalah menara tipe AA double circuit dan asumsi curah petir (Isokreaunic Level): $91 \mathrm{sambaran} / \mathrm{km}^{2} /$ tahun.

Perancangan sistem proteksi petir terdiri dari 2 komponen utama yaitu kawat tanah pada menara dan arrester surja serta rating BIL peralatan gardu induk [9]. Pembahasan mengacu pada analisis sistem proteksi petir di menara mengingat proteksi dengan kawat tanah (Overhead Groundwire) letaknya paling atas dan paling dekat dengan sambaran petir langsung, dibandingkan dengan arrester surja. Berikut merupakan konstruksi menara yang digunakan dalam penelitian [10]:

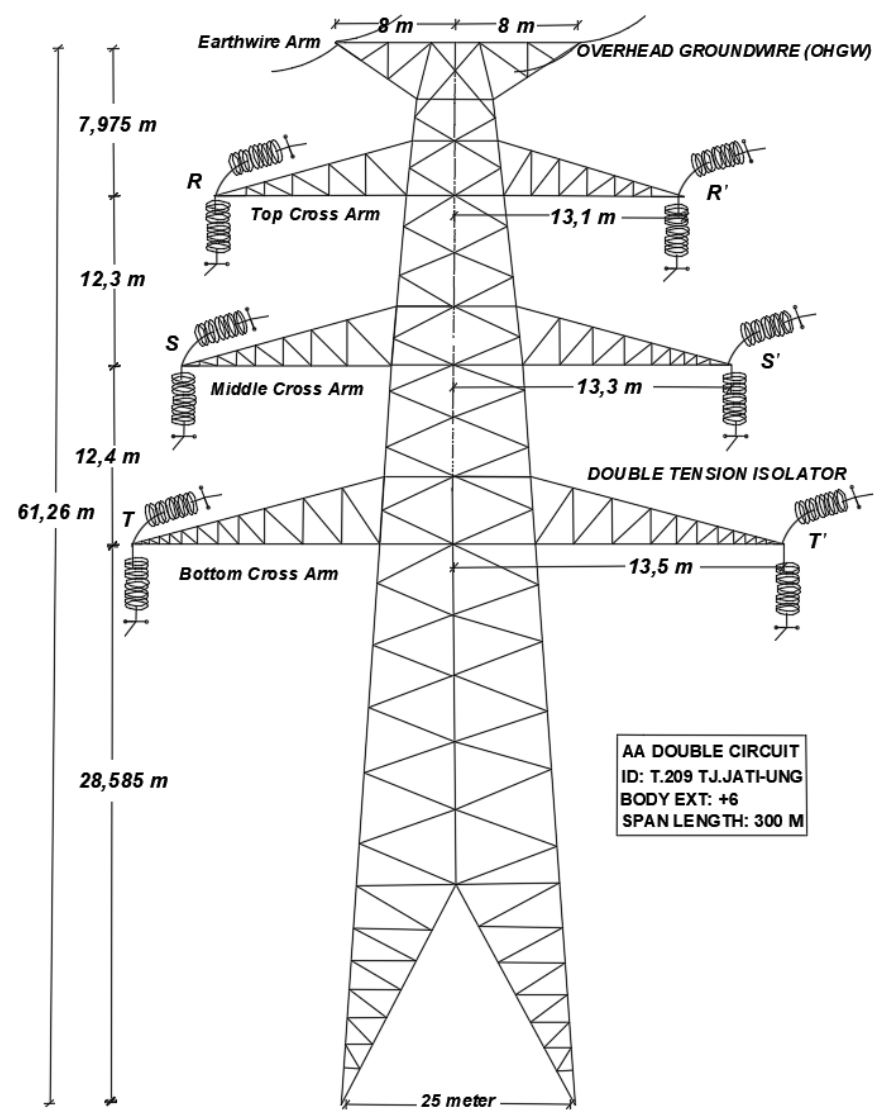

Gambar 2. Menara Transmisi Tipe AA

Hasil Perhitungan tinggi rata-rata $h$ kawat tanah dan kawat fasa di atas tanah seperti ditam pilkan tabel berikut:

Tabel 1. Parameter Data Tinggi Kawat Fasa, Kawat Tanah, Andongan

\begin{tabular}{|c|c|c|c|}
\hline Parameter data & Nilai (meter) & h=ht-2/3 s & Keterangan \\
\hline$h t$ (kawat tanah) & 61,260 & 52,92 & - \\
\hline$h t$ (kawat fasa R dan R') & 53,285 & 44,95 & - \\
\hline$h t$ (kawat fasa S dan S') & 40,985 & 32,65 & - \\
\hline$h t$ (kawat fasa T dan T') & 28,585 & 20,25 & Topografi: lapangan terbuka \\
\hline Andongan & 12,500 & \multicolumn{3}{|c}{} \\
\hline
\end{tabular}


Tabel 2. Radius Korona (Rc) dari Konduktor Berkas Masing-masing Fasa

\begin{tabular}{|c|c|c|c|}
\hline & $\mathrm{R}$ & $R+r_{\text {eki }}$ & Rc (meter) \\
\hline Kawat fasa R dan R' & 0,264 & $0,264+0,1948$ & 0,4588 \\
\hline Kawat fasa S dan S' & 0,283 & $0,283+0,1948$ & 0,4778 \\
\hline Kawat fasa T dan T' & 0,318 & $0,318+0,1948$ & 0,5128 \\
\hline
\end{tabular}

Tabel 3. Impedansi Surja,Arus Petir Minimum, Jarak Sambaran Minimum Kawat Masing-masing Fasa, Daerah Tidak Terlindungi dengan $\beta \mathrm{s}=0,8^{*} \mathrm{~S}$

\begin{tabular}{|c|c|c|c|c|}
\hline & $Z_{\varnothing}(\Omega)$ & $I \min (\mathrm{kA})$ & $S \min ($ meter $)$ & $X s($ meter $)$ \\
\hline Kawat fasa R dan R' & 341,404 & 13,544 & 61,384 & $4,189(\geq 0)$ \\
\hline Kawat fasa S dan S' & 320,843 & 14,412 & 64,713 & $-0,21(\leq 0)$ \\
\hline Kawat fasa T dan T' & 289,736 & 15,960 & 70,575 & $-6,439(\leq 0)$ \\
\hline
\end{tabular}

Dengan menggunakan metode bola bergulir (rolling sphere method). Amplituda arus sambaran pertama menurut Armstrong dan Whitehead diturunkan dari koefisien rumus jarak sambar lidah petir sebagai radius bola (Formula Wagner dari eksperimen Paus dan Watanabe):

$$
r_{s}=6,71 \times I^{0,85} \text { meter, }
$$

Dengan I adalah arus puncak sambaran pertama (kA). Evaluasi metode ini menggunakan arus puncak sambaran sesuai karakteristik petir polaritas positif dengan probabilitas sebesar $50 \%$ yaitu sebesar $18 \mathrm{kA}: r_{s}==6,71 \times 18^{0,85}=78,23$ meter $=$ radius bola bergulir $=$ jarak sambar lidah petir

Berdasarkan hasil percobaan tersebut, sambaran petir langsung (direct lightning) pada kawat tanah menyebabkan tegangan yang timbul pada saluran dapat mencapai hingga $710 \mathrm{kV}$ untuk fasa R. Tegangan yang berjalan pada kawat fasa $\mathrm{R}$ terkena dampak paling besar dibanding dengan fase lainnya. Hal tersebut dikarenakan fasa R memiliki letak kawat yang paling dekat dengan kawat tanah (Overhead Groundwire).

Besarnya gangguan kegagalan perisaian (shielding failure) akibat sambaran petir langsung pada kawat fasa $\mathrm{R}$ terkena adalah 0,383 gangguan/ $100 \mathrm{~km} /$ tahun diperoleh dari formula

$$
N_{S F}=0,0015 . I K L . X s .(P \min -\text { Pmaks })
$$

Back flashover pada isolator menara berupa lompatan api dapat mengakibatkan isolator kaca pecah dan memutuskannya dengan saluran kawat fasa yang berada di bawah rentengannya. Jumlah gangguan akibat hal tersebut perlu diukur dengan melihat apakah tegangan timbul di isolator melebihi tegangan kritis lompatan api. Dengan parameter pada sub-bab 4.1, maka dapat dihitung gangguan petir akibat back flashover dengan menggunakan: data koefisien kawat bayangan untuk kawat fasa dan kawat tanah dari gambar berikut:

Dengan asumsi tahanan menara $\mathrm{R}=10 \mathrm{Ohm}$ dan koefisien-koefisien berdasarkan perhitungan sebelumnya maka probabilitas gangguan akibat back flashover, diperoleh: 
Tabel 4. Perhitungan Probabilitas Gangguan Akibat Back Flashover

\begin{tabular}{|c|c|c|c|c|}
\hline $\begin{array}{c}\mathrm{T} \\
\text { ( } \mu \text { det) }\end{array}$ & Io $(\mathbf{k A})$ & $\begin{array}{c}\text { Seringnya terjadi } \\
(\%)\end{array}$ & $\begin{array}{c}\mathbf{V i} \\
(\mathbf{k V})\end{array}$ & $\begin{array}{l}\mathrm{V}_{50 \%} \\
(\mathbf{k V}) \\
\end{array}$ \\
\hline \multirow{5}{*}{$\begin{array}{c}0,5 \\
(70 \%) \\
\end{array}$} & 60 & 90 & 1354,102 & \multirow{5}{*}{6296,5} \\
\hline & 80 & 8 & 1805,470 & \\
\hline & 100 & 1,2 & 2256,837 & \\
\hline & 160 & 0,5 & 3610,940 & \\
\hline & 200 & 0,3 & 4513,675 & \\
\hline \multirow{5}{*}{$\begin{array}{c}1 \\
(23 \%) \\
\end{array}$} & 60 & 90 & 831,116 & \multirow{5}{*}{4384,5} \\
\hline & 80 & 8 & 1108,155 & \\
\hline & 100 & 1,2 & 1385,194 & \\
\hline & 160 & 0,5 & 2216,310 & \\
\hline & 200 & 0,3 & 2770,388 & \\
\hline \multirow{5}{*}{$\begin{array}{c}1,5 \\
(22 \%) \\
\end{array}$} & 60 & 90 & 656,788 & \multirow{5}{*}{3649,1} \\
\hline & 80 & 8 & 875,717 & \\
\hline & 100 & 1,2 & 1094,646 & \\
\hline & 160 & 0,5 & 1751,434 & \\
\hline & 200 & 0,3 & 2189,292 & \\
\hline \multirow{5}{*}{$\begin{array}{c}2 \\
(48 \%) \\
\end{array}$} & 60 & 90 & 569,623 & \multirow{5}{*}{3247,5} \\
\hline & 80 & 8 & 759,498 & \\
\hline & 100 & 1,2 & 949,372 & \\
\hline & 160 & 0,5 & 1518,995 & \\
\hline & 200 & 0,3 & 1898,744 & \\
\hline
\end{tabular}

Probabilitas gangguan akibat Back Flashover $\left(\mathrm{P}_{\mathrm{FL}}\right)$ bernilai 0\%, artinya tidak terdapat kemungkinan gangguan akibat back flashover. Sangat kecil kemungkinan gangguan akibat back flashover dinilai dari $\mathrm{Vi}$ (tegangan timbul di isolator dalam $\mathrm{kV}$ ) tidak ada yang melebihi nilai dari $\mathrm{V}_{50 \%}$ (tegangan lompatan api di rentengan isolator dalam $\mathrm{kV}$ ). Baik untuk waktu muka gelombang petir $0,5 \mu \mathrm{s} ; 1 \mu \mathrm{s} ; 1,5 \mu \mathrm{s} ; 2 \mu \mathrm{s}$ dengan arus puncak petir $60 \mathrm{kA}, 80 \mathrm{kA}, 100 \mathrm{kA}, 150 \mathrm{kA}, 200 \mathrm{kA}$ memiliki tegangan timbul di isolator yang lebih kecil daripada tegangan lompatan api, sehingga tidak ada probabilitas gangguan yang akan terjadi akibat back flashover $\left(\mathrm{P}_{\mathrm{FL}}=0 \%\right)$. Analisis hasil penyebab probabilitas gangguan akibat back flashover $\mathrm{P}_{\mathrm{FL}}=0 \%$ disebabkan oleh beberapa hal berikut: Jarak aman antara kawat fasa dan kawat tanah dan kawat fasa ke kawat fasa sangat besar sehingga kekuatan isolasi dari udara di tempat-tempat tersebut cukup besar untuk mencegah terjadinya lompatan api. Panjang rentengan isolator yang cukup panjang (3,95 meter) pada menara dengan model double tension, ada 2 isolator yang berdekatan dengan satu menara pada satu sirkuit saluran, sehingga tegangan timbul isolator sangat jauh untuk mencapai tegangan lompatan api.

Kepingan isolator kaca yang berjumlah 30 menjadi faktor bahwa tegangan isolator yang dibutuhkan untuk melebihi tegangan lompatan api sangatlah besar.

Untuk menghitung gangguan petir pada menara perlu diketahui probabilitas peralihan lompatan api menjadi busur api (power follow current) yang menimbulkan gangguan. Dengan asumsi jumlah sambaran $60 \%$ pada total sambaran dan probabilitas gangguan $0 \%$ maka:

$$
B F O=1 \times 0,6 \times N_{L} \times P_{F L}=1 \times 0,6 \times 447 \times 0=0 \text { gangguan } / 100 \mathrm{~km} / \text { tahun }
$$

Sehingga dapat dihitung Lightning Performance sebagai jumlah gangguan sambaran petir langsung untuk menentukan parameter tingkat keandalan proteksi SUTET $500 \mathrm{kV}$ tipe AA: 


$$
L P=N_{S F}+B F O=(0,383+0) \text { gangguan } / 100 \mathrm{~km} / \text { tahun }
$$

Artinya jumlah gangguan akibat sambaran petir adalah 0,383 gangguan pada saluran transmisi per $100 \mathrm{~km}$ panjang saluran per tahun. Nilai keandalan lightning performance untuk 0,383 gangguan per $100 \mathrm{~km}$ per tahun adalah good grounding and shielding. Pemasangan extended mast terminal pada menara terdekat gardu induk (gantry) serta menara-menara SUTET pada posisi belokan (aspan) berupa lightning rod eksisting sudah cukup baik untuk menangani gangguan akibat sambaran petir langsung.

Lightning arrester didesain untuk melindungi peralatan lain yang ada didalam sistem transmisi tenaga listrik dari tegangan surja (kasus ini surja petir) dengan cara membatasi surja tegangan lebih yang datang dan mengalirkannya ketanah dengan aman tanpa menyebabkan kerusakan peralatan [11]. Tegangan pengenal arrester/ rating arrester $(U c)$. Jika jegangan sistem $500 \mathrm{kV}$ (fasa-fasa) dan koefisien pentanahan bernilai 1 maka:

$$
U_{C}=\text { Tegangan sistem } x \text { koefisien pentanahan } x 1,1
$$

$U_{C}=500 \mathrm{kV} x 1 \times 1,1=550 \mathrm{kV}$. Oleh karena itu dipilih rating arrester yang mendekati atau sama dengan $U c$.

Peralatan gardu induk paling penting untuk mendapatkan perlindungan yang baik dari surja petir seperti trafo daya, CVT (Capacitor Voltage Transformer), CT (Current Transformer), DS (Disconnecting Switch), BSI (Bus Support Insulator), dan CB (Circuit Breaker). Tingkat isolasi dasar yaitu BIL peralatan tersebut menjadi hal yang penting dalam sistem proteksi yang akan diuji faktor perlindungan (FP) atau margin proteksi (MP) [12]. Berikut merupakan data BIL peralatan gardu induk berdasarkan datasheet studi lapangan dan literatur:

Tabel 5. Rated Lightning Impulse Withstand Voltage Equipment Case 1 (1,2/ $50 \mu \mathrm{s})$

\begin{tabular}{|c|c|c|}
\hline & \multicolumn{2}{|c|}{ BIL (Basic Impuls Insulation Level) } \\
\hline Peralatan GITET Skenario & Skenario 1 & Skenario 2 \\
\hline Transformator daya & $1425 \mathrm{kV}$ & $1550 \mathrm{kV}$ \\
\hline Capacitor Voltage Transformer (CVT) & $1550 \mathrm{kV}$ & $1800 \mathrm{kV}$ \\
\hline Current Transformer (CT) & $1550 \mathrm{kV}$ & $1800 \mathrm{kV}$ \\
\hline Disconnecting Switch (DS) & $1550 \mathrm{kV}$ & $1800 \mathrm{kV}$ \\
\hline Bus Support Insulator (BSI) & $1550 \mathrm{kV}$ & $1800 \mathrm{kV}$ \\
\hline Circuit Breaker (CB) & $1550 \mathrm{kV}$ & $1800 \mathrm{kV}$ \\
\hline
\end{tabular}

Arrester sebaiknya ditempatkan sedekat mungkin pada jepitan transformator dan peralatan gardu induk lainnya. Dalam hal ini ada jarak maksimum yang diizinkan antara peralatan gardu induk yang dilindungi dengan arrester yaitu S, dimana:

$$
E p=\left(E a+2 x \frac{A \cdot S}{v}\right)
$$

$E a=$ tegangan percik $/$ pelepasan arrester $=560 \mathrm{kV}, v=$ kecepatan rambat gelombang di udara $=300 \mathrm{~m} / \mu \mathrm{s}, A=\frac{d U}{d t}=$ kecuraman dari gelombang datang $(\mathrm{kV} / \mu \mathrm{s})=1000 \mathrm{kV} / \mu \mathrm{s}$ (berdasarkan rekomendasi IEC 1958 Lightning Arrester) 
Tabel 6. Jarak Maksimum Arrester Surja Terhadap Transformator, CVT, CT, DS, BSI, dan CB

\begin{tabular}{|c|c|c|c|}
\hline BIL $(\boldsymbol{k V})$ & $E p=\left(E a+2 x \frac{A . S}{v}\right)$ & Smax (meter $)$ & Keterangan \\
\hline 1425 & $1425=\left(560+2 x \frac{1000 . S}{300}\right)$ & 129,75 & terhadap trafo \\
\hline 1550 & $1550=\left(560+2 x \frac{1000 . S}{300}\right)$ & 148,5 & $\begin{array}{c}\text { terhadap trafo, CVT, CT, DS, } \\
\text { BSI, dan CB. }\end{array}$ \\
\hline 1800 & $1800=\left(560+2 x \frac{1000 . S}{300}\right)$ & 186 & $\begin{array}{c}\text { terhadap CVT, CT, DS, BSI, } \\
\text { dan CB }\end{array}$ \\
\hline
\end{tabular}

Tingkat perlindungan arrester ini akan menentukan margin proteksi dari BIL peralatan gardu induk yang dilindungi oleh arrester. $T P$ arrester $=560 \mathrm{kV} x 1,1$ (panjang kawat dan toleransi pabrik) $=616 \mathrm{kV}$. Margin proteksi antara arrester dan peralatan gardu induk yang dilindungi harus lebih dari $20 \%$ atau dalam formula

$$
\text { Margin Proteksi }=\text { MP }=\frac{\text { BIL Equip-TParrester }}{\text { BIL Equip }} \times 100 \% \geq 20 \%
$$

Tabel 7. Margin Proteksi Peralatan GITET Case $2(1,2 / 50 \mu \mathrm{s})$

\begin{tabular}{|c|c|c|c|c|c|c|}
\hline Peralatan & BIL Equip & $\begin{array}{c}\text { Margin } \\
\text { Proteksi }\end{array}$ & Kondisi & BIL Equip & $\begin{array}{c}\text { Margin } \\
\text { Proteksi }\end{array}$ & Kondisi \\
\hline Trafo Daya & $1425 \mathrm{kV}$ & $56,77 \%$ & Aman & $1550 \mathrm{kV}$ & $60,26 \%$ & Aman \\
\hline CVT & $1550 \mathrm{kV}$ & $60,26 \%$ & Aman & $1800 \mathrm{kV}$ & $65,77 \%$ & Aman \\
\hline CT & $1550 \mathrm{kV}$ & $60,26 \%$ & Aman & $1800 \mathrm{kV}$ & $65,77 \%$ & Aman \\
\hline DS & $1550 \mathrm{kV}$ & $60,26 \%$ & Aman & $1800 \mathrm{kV}$ & $65,77 \%$ & Aman \\
\hline BSI & $1550 \mathrm{kV}$ & $60,26 \%$ & Aman & $1800 \mathrm{kV}$ & $65,77 \%$ & Aman \\
\hline CB & $1550 \mathrm{kV}$ & $60,26 \%$ & Aman & $1800 \mathrm{kV}$ & $65,77 \%$ & Aman \\
\hline
\end{tabular}

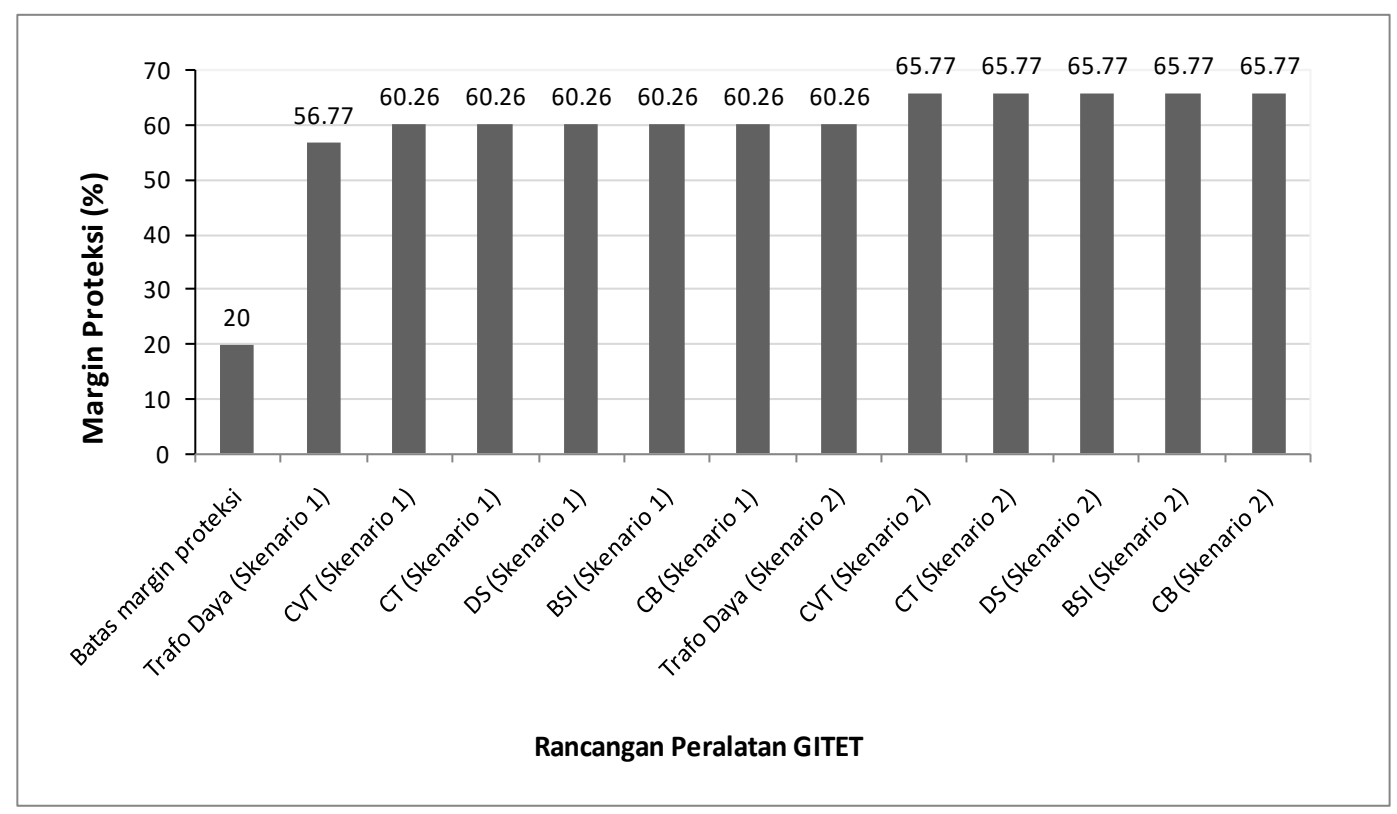

Gambar 3. Margin Proteksi Peralatan GITET Skenario 1 dan 2 


\section{Energi dan Kelistrikan: Jurnal Ilmiah}

Vol. 11, No. 2, Juli - Desember 2019, P-ISSN 1979-0783, E-ISSN 2655-5042

https://doi.org/10.33322/energi.v11i2.769

Berdasarkan analisa perhitungan margin proteksi di atas maka dapat disimpulkan bahwa untuk kedua skenario, peralatan-peralatan Gardu Induk memenuhi standard aman dengan margin proteksi lebih dari $20 \%$ BIL. Peralatan tersebut memiliki rated lightning impulse withstand untuk surja petir $1,2 / 50 \mu$ s yang memenuhi standard aman.

\section{KESIMPULAN DAN SARAN}

Pengujian rancangan berdasarkan konsep lightning performance menunjukkan SUTET 500 $\mathrm{kV}$ tipe AA memiliki pentanahan dan perisaian yang baik, untuk meningkatkan keandalan sistem proteksi maka pada tower belokan/ aspan dan terdekat di gardu induk dipasang sepasang lightning rod (EMT: Extended Mast Terminal) di masing-masing ujung lengan kawat tanah (earthwire crossarm).

\section{UCAPAN TERIMA KASIH}

Penulis ingin menyampaikan terima kasih kepada Bapak Aris selaku Supervisor di PLN P3B APP Semarang dan Bapak Yuda di GITET Ungaran yang telah membantu penulis dalam meyiapkan data, melakukan penelitian, dan pembuatan karya ilmiah ini.

\section{DAFTAR PUSTAKA}

[1] Haryono, T. (2013) “Indonesia, Negara Dengan Frekuensi Petir Sangat Tinggi," .

[2] Adbul, S. Fenomena Petir. Jakarta: Universitas Trisakti Publisher.

[3] Nugroho, A. Syakur, A. (2005). "Penentuan Lokasi Pemasangan Lightning Masts Pada Menara Transmisi Untuk Mengurangi Kegagalan Perlindungan Akibat Sambaran Petir," J. Transm., vol. Vol. 7 No.

[4] IEEE 10.1109/ IEEESTD.2011.5754137. (2011). "IEEE Standard C.62. 82.1-2010for Insulation Coordination, 'Definitions, Principles, and Rules', IEEE Insulation In General”.

[5] PT.PLN Persero dan Teknik Elektro Universitas Diponegoro. (2011). Aplikasi Perangkat Lunak ATP/EMTP Pada Sistem. Pusat Pendidikan dan Pelatihan (PUSDIKLAT) PT.PLN.

[6] G. T. Elektro. (2012). "ANALISIS SISTEM PROTEKSI PETIR ( LIGHTING PERFORMANCE ) PADA SUTT $150 \mathrm{kV}$ SISTEM SULAWESI SELATAN," in Prosiding Hasil Penelitian Desember 2012, vol. 6, pp. 978-979.

[7] Fransisco. (2012). "Perhitungan Jumlah Gangguan Pada Isolator Transmisi Akibat Sambaran Petir Langsung (Studi Kasus: Transmisi 275 kV Galang-Binjai,”. Universitas Sumatera Utara Medan.

[8] Abduh, S. (2009). "Analisis Gangguan Petir Akibat Sambaran Langsung Pada Saluran Transmisi Tegangan Ekstra Tinggi 500 kV,". J. Tek. Elektro FTI Fenruari, vol. 8.

[9] PT. PLN (PERSERO) dan Kementrian ESDM Republik Indonesia dan MULTIFAB CONSORTIUM. "Book 5 of 13 As Built Record 500 KV And 150 KV Susbtation and Transmission Lines Project,". Jakarta.

[10] PT. PLN (PERSERO) dan Kementrian ESDM Republik Indonesia. (2018). "Book 3 of 13 As Built Record 500 KV And 150 KV Susbtation and Transmission Lines Project.,". Jakarta.

[11] Paraisu, S. S. M. S. Lisi, F. Patras, L. S. (2013). "Analisa Rating Lightning Arrester Pada Jaringan Transmisi 70 kV Tomohon-Teling,". E-Jurnal Tek. Elektro dan Komput. Fak. Tek. Univ. Sam Ratulangi.

[12] Jaya, A. (2000). "Koordinasi Isolasi Pada Gardu Induk 500 kV Yang Memperhatikan Bentuk Gelombang Surja Petir,". Universitas Gadjah Mada.

[13] Siemens AG Energy Sector Power Transmission Division. (2011). High Voltage Products. 
Erlangen, Germany.: Siemens AG Energy Sector.

[14] PT. PLN. (2018) "RUPTL PLN 2018-2027,".

[15] Razevig, D. (1979). "High Voltage Engineering," 1st ed. New Delhi, India: Kahnna Publisher.

[16] Hutauruk, T. (1989). “Gelombang Berjalan dan Proteksi Surja,” 1st ed. Bandung: Erlangga.

[17] Junaidi, A. (2017). "Analisis Unjuk Kerja Saluran Udara Tegangan Tinggi 500 kV 2 Saluran dan 4 Saluran Di Sumatera," in Prosiding Seminar Ilmiah Nasional Pascasarjana Juli2017. 